\title{
Composition of the Archaean mantle and continental crust in the western Dharwar Craton, India
}

\author{
ARATHY RAVINDRAN ${ }^{1}$, KLAUS MEZGER ${ }^{1}, \mathrm{~S}$. \\ BALAKRISHNAN $^{2}$ \\ ${ }^{1}$ Institut für Geologie, Universität Bern, Bern, Switzerland \\ ${ }^{2}$ Department of Earth Sciences, Pondicherry University, \\ Puducherry, India
}

The composition of the primordial mantle has a primary influence on the amount and composition of Earth's early continental crust. Studying the processes associated with ancient crust formation is complicated due to the limited exposure of Hadean-Archaean $(>3.2 \mathrm{Ga})$ rocks. The western Dharwar Craton, India, (dominantly $\sim 3.4 \mathrm{Ga}$ ) is one of the few well-accessible Paleoarchaean cratons that host both high temperature and pressure (deep) melts like komatiites and high to medium pressure (shallow) melts like TTGs. Detrital zircons yield a maximum ${ }^{207} \mathrm{~Pb} / 206 \mathrm{~Pb}$ age of $\sim 3.6 \mathrm{Ga}$ which defines the oldest crustal components of the craton (Guitreau et al., 2017). Based on trace element abundances $\left({ }^{147} \mathrm{Sm} /{ }^{144} \mathrm{Nd} \sim 0.16 ;{ }^{176} \mathrm{Lu} /{ }^{177} \mathrm{Hf} \sim 0.02\right)$ and $\mathrm{Sr}$ isotopes (Ravindran et al., 2020), this crust was dominantly mafic.

Hafnium and Nd isotopes of TTGs and greenstone mafic rocks of the western Dharwar Craton are well-correlated and support a mildly depleted mantle as their main source. In contrast, ultramafic rocks (komatiites, komatiitic basalts, cumulates) show a very strong depletion and 'decoupled' Hf$\mathrm{Nd}$ isotope systematics. The initial $\varepsilon \mathrm{Hf}$ of these ultramafic rocks range from +3 to +20 . Such extreme initial isotope ratios have also been observed in ultramafic rocks of other Paleoarchaean cratons (e.g. Hoffmann \& Wilson, 2017). The whole rock Lu-Hf age of $3182 \pm 170 \mathrm{Ma}$ agrees with the U-Pb zircon age (3228 $\pm 22 \mathrm{Ma})$ of mafic rocks in that area which further clarifies that the Lu-Hf system has not been disturbed by late metamorphism. The komatiitic rocks could derive from deeper mantle sources that were modified by fractionation of garnet and/or perovskite (?) during early differentiation which resulted in decoupling of Lu-Hf from Sm-Nd. Thus, the ultramafic melts derived from deep mantle sources that preserved a memory of early mantle differentiation. The heterogeneous composition of the Archaean mantle significantly influenced the composition of the average continental crust in the Dharwar Craton.

References

Guitreau et al. (2017) Prec. Res. 302, 33-49

Ravindran et al. (2020) Prec. Res. 337, 105523

Hoffmann and Wilson (2017) Chem. Geol. 455, 6-21 